\title{
Singaporean pre-service music teachers' identities, motivations and career intentions
}

\section{Background and context}

This article investigates the career motivations and intentions of pre-service music teachers (PSMTs) in Singapore. We begin with an overview of the context and study approach before presenting and discussing the findings. We conclude with implications for educators and recruiters. Implications include the need for open discussion with PSMTs about their possible future selves and careers, to rethink the recruitment of pre-tertiary students into teaching programs, and to track and understand teacher attrition.

\section{Singapore as the context for music education research}

The need to understand music teachers' identities as musicians and as teachers has long been articulated by western music educators (see Dolloff, 1999; Hargreaves, Marshall, \& North, 2003; MacDonald, Hargreaves, \& Miell, 2002). Alongside this, concerns about teacher training efficacy and teacher attrition have prompted studies in the United Kingdom (UK) (Hargreaves \& Marshall, 2003), Australia (Cleaver \& Ballantyne, 2013; [hidden] \& Stanberg, 2006), the USA ([hidden] \& Freer, 2012; Dollof, 1999) and Europe (Ballantyne, Kerchner \& Arostegui, 2012; Triantafyllaki, 2010). In Singapore, however, these areas remain underresearched.

Singaporean pre-service teacher (PST) research has hitherto focused almost exclusively on motivation rather than teacher identity or beliefs (see Lau, 1968; Soh, 1981, 1989 \& 1998; Goh \& Atputhasamy, 2001; Lim, Low, Ch'ng, \& Goh, 2005). In 2012, Low, Hui, Taylor and $\mathrm{Ng}$ 's review of research on initial teacher education in Singapore (from 1999-2010) identified just five articles pertaining to student teachers' attitudes and beliefs about teaching and learning. Three of these concerned technology in teaching and the remaining two focused on espoused beliefs of English, Mathematics and Science teachers (Dixon \& Liang, 2009) and teacher identity expressed within e-portfolios (Zhou, Chye, Koh, \& Liu, 2013).

Understanding teachers' sense of identity is "key to understanding teachers and teaching as a profession" (Alsagoff, 2013, p. 2). Indeed, Low and her team (2009) suggest that effective teachers in the 21 st century must "first understand their own values and beliefs in the context of an increasingly complicated local and international environment". Low called for largescale, systematic investigations that might inform improvements to initial teacher education (ITE) in Singapore. Regrettably, such studies are only now in progress. 
The timing for this study, conducted in 2014, was crucial for three reasons. First, the need for research specific to the arts had taken on greater urgency since the 2009 Ministry of Education (MOE) Primary Education Review and Implementation Committee recognised the importance of arts education and stated targets for increased provision (MOE, 2009). Second, music teacher attrition in Singapore was relatively high compared to the general teacher attrition rate. Teacher attrition had fallen in Singapore from $\sim 5 \%$ in the mid-1990s (The Straits Times, March 21, 1996) to 2-3\% over the next decade (MOE, 2006) and had since remained at around 3\% (MOE, 2013). Although there are no MOE statistics on the attrition of music teachers, anecdotal knowledge suggested that teacher attrition was far higher among music teachers. Finally, the MOE had set a goal of increasing the number of art and music teachers from 1300 in 2012 to 1900 by 2020 (MOE, 2012). However, even with the use of incentives such as scholarships for pre-tertiary students, the MOE was finding it difficult to attract sufficient PSMTs.

\section{Understanding identity development}

Identity formation begins long before university study (Bernard, 2005; Smilde, 2009) and is a central determinant of self-concept; and yet identity formation during university study underpins practising teachers' conceptions of their professional self and their teaching practice (Hawkey, 1996). Moreover, Hargreaves et al. (2002) contend that the professional identities of teachers change little after graduation. It follows that for teachers to avoid praxis shock (Mark, 1998), professional identity needs to be explored and negotiated during teacher training (Ballantyne, 2005; McCormack \& Thomas, 2003).

The identity formation of PSMTs can be challenged in several ways, including by preconceptions of teacher roles, sometimes gained from career previews. Brand \& Dolloff (2002, p. 28) assert that pre-service music teachers can hold stereotypical images of teaching to the extent that "fantasy and reality strikingly compete". As such, "time needs to be devoted to enabling students' fantasized music teacher to be demystified" (p. 28) through regular opportunities for teaching experience and self-examination.

For PSMTs, identity can also involve multiple efficacies and multiple selves or identities. In the case of music these might include identities as a musician, a music teacher and a teacher in more general terms. Conflicting identities can relate to unmet performance ambitions and also to a hierarchy in which teaching is positioned as a financially "safe" career option in contrast to careers in music performance. As such, the music education degree has 
sometimes been seen as a "back-up" (Roberts, 1993) to a conservatoire-type performance degree.

In Singapore, as elsewhere, many music graduates seek graduate-level teacher certification. In contrast, few music education graduates resign their teaching positions to pursue a career in performance, although a sizeable number leave to teach music privately. The institution in which the study was undertaken is the sole provider of music teachers for Singapore schools, and the institution's music educators know from their strong relationships with teachers and alumni that music teacher transition from schools to private teaching accounts in part for the current shortage of school music teachers.

The study reported here aims to provide insights into the professional identity and beliefs among Singaporean PSMTs, including their hopes and fears for the future. We hoped that the findings would inform recruitment and retention efforts on the one hand and music teacher preparation programmes on the other.

\section{The study}

\section{Theoretical framework}

This study was grounded in the theoretical framework of possible selves (Marcus \& Nurius 1986), which considers people's projections about their desired, expected or feared future selves. As Freer (2010) indicates, the framework differs from other models because of its focus on future-oriented thinking, which can lead to strategies for the realisation or avoidance of possible future selves.

Freer's 2010 systematic review of possible selves research led him to warn of the need "to clearly articulate 'possible selves' and how the construct is employed within research methodology and analyses" (p. 24). MacIntyre, Schnare and Doucette (2012) responded with a study that identified categories of expected, hoped-for and feared selves among musicians. Of interest, the authors found expected selves among musicians to be negative and hoped-for selves to be positive. Musicians' fears related to poor musicianship or knowledge, injury or illness, financial instability, and lack of social connections and recognition. Hoped-for selves related to positive features such as success, enjoyment, self-improvement and social connectivity. In line with research on emerging teacher identity (see Beijiaard, Meijer, \& Verloop, 2004; Hamman at al., 2010), the possible selves framework positions teacher identity as an evolving, socially constructed and multifarious process. This locates the framework as a promising strategy for fostering future-oriented thinking and planning among higher education students (Oyserman \& James, 2011; Packard \& Conway, 2006). 


\section{The Singapore Context}

This study was situated within the National Institute of Education (NIE), a college of the Nanyang Technological University (NTU) in Singapore. NIE is the sole provider of preservice teacher education for the mainstream schools in Singapore, offering diploma, bachelor and postgraduate diploma teacher certification programmes. The teacher preparation programmes differentiate between teaching at the primary (age 7-12) and secondary (age 1317) levels. In the case of the Postgraduate Diploma in Education (PGDE), programs include a focus on the junior college levels (age 17-19). Responding to the 2009 Report of the Primary Education Review and Implementation Committee (MOE, 2009), the MOE began to move toward single-subject specialisation for primary level music teachers. To meet the associated training need, NIE introduced an advanced diploma in music education that enables in-service teachers to become primary school music specialists, and a postgraduate diploma for primary level music specialisation.

In Singapore schools, music is offered at the general level and as a national examination subject at "O" (ordinary), "N/T" (normal/technical) and "A" (advanced) levels; the N/T level is a special stream for students more inclined towards the technical subjects. Specialist music teachers deliver the music national examination subjects. General music teachers may possess music as their second or, in the case of primary, third teaching subject. The prerequisite for entry to teacher training is Grade 6 practical and Grade 5 music theory or equivalent.

At NIE, PSMTs have various opportunities to teach in school. Many PSMTs undertake contract teaching work arranged by the MOE before starting their teacher training, and graduate PSMTs usually begin their one-year training programme with a four-week Enhanced School Experience. In the four-year undergraduate music education programme, students undertake a two-week school experience placement at the beginning of their second year. In subsequent years they progress through a five-week teaching assistantship school placement, a five-week teaching practicum and, in their graduating year, a ten-week final teaching practicum. The two-year diploma offers PSMTs a five-week and a ten-week teaching practicum. The one-year PGDE, due to the limited programme duration, allows for only one teaching practicum.

In an effort to ensure quality teachers, the MOE offers scholarships for students; music, as a school-based teaching subject, has benefitted from this general recruitment drive. Schoolaged scholarship holders usually undertake a three-month internship before accepting a scholarship. The scholarships fund initial music studies in music either overseas or locally. 
Students also receive either a monthly salary or a yearly stipend. The majority of PSMTs at NIE are sponsored by the MOE for their teacher training. Depending on the duration of the sponsorship and whether the Ministry also sponsored their earlier music studies, students are contractually bound (bonded) to teach for three or more years in MOE schools.

\section{The participants}

Once ethics approvals were obtained, students were invited to participate via email and also in person during their classes. Participation was voluntary and students were advised that their responses would remain anonymous. Student voices in this paper are coded according to participant number and course: BA (Bachelor of Arts in Education); PGP (PGDE in primary music teaching); and PGS (PGDE in secondary music teaching).

The study invited participation from sixty undergraduate and PGDE PSMTs who were undertaking music education studies. At the time of the study, 38 music majors were enrolled in the four-year Bachelor of Arts (Education) program. Given that our focus was on PSMTs, we excluded two serving teachers who had taught for many years and were on study leave to pursue a degree. Of the 22 PGDE PSMTs, 14 were in the secondary track with music as either their first or second teaching subject, and eight were training to be primary, single-subject music specialists; both programmes were one-year in duration. In the BA (Education) programme, students in the primary track are trained to teach three subjects of which music is typically the third. Those in the secondary track and graduate diploma learn to teach two subjects.

Thirty-five PSMTs responded to the call for participants. Of the $14(63.6 \%)$ graduates who responded, four ( $50 \%$ of students) were from the primary track and ten ( $71.4 \%$ of students) from the secondary track. Undergraduate participants numbered 21 (55.3\%). Two participants were first year students, seven were second years, one was in the third year of study and eleven were in their final year. Participant ages in the graduate cohort ranged from 23 to 37 (mean age 27.5$)$, and ten (71\%) were female. Being graduate students, participants had a range of prior qualifications and experiences as shown at Table 1. Music was the first teaching subject for all but three students. Participant ages in the undergraduate cohort ranged from 21 to 31 (mean age 23.7), and twelve (57\%) were female. Also shown at Table 1, six students already held diplomas, four of which were in music or music teaching. One student noted a prior degree in finance.

\section{Table 1: Work history / qualifications of the participants}




\begin{tabular}{|c|c|c|}
\hline Work history (multiple response) & \multicolumn{2}{|l|}{ Number } \\
\hline Instrumental music teacher & \multicolumn{2}{|l|}{7} \\
\hline No work experience & \multicolumn{2}{|l|}{5} \\
\hline Performer & \multicolumn{2}{|l|}{4} \\
\hline Tutor or teacher other than music & \multicolumn{2}{|l|}{4} \\
\hline Relief teacher & \multicolumn{2}{|l|}{3} \\
\hline Non-arts work & \multicolumn{2}{|l|}{3} \\
\hline Ensemble director & \multicolumn{2}{|l|}{1} \\
\hline \multicolumn{3}{|c|}{$\begin{array}{l}\text { Graduate students: one-year graduate teaching degree }(n=14) \\
\text { Secondary }(n=10) \text { and primary }(n=4) \text { school pre-service music teachers }\end{array}$} \\
\hline Prior qualifications & Work history (multiple response) & Number \\
\hline BMus/MMus/BMus (hons) $(\mathrm{n}=10)$ & Performer/composer/ensemble director & 7 \\
\hline $\mathrm{BSc} / \mathrm{BA}(\mathrm{n}=4)$ & Role unrelated to music or teaching & 5 \\
\hline & Instrumental music teacher & 5 \\
\hline & Relief teacher & 2 \\
\hline & No work experience & 2 \\
\hline & Other arts role & 1 \\
\hline
\end{tabular}

\section{Data collection and analysis}

Structured surveys are the most widely used tool in research that utilises the possible selves framework (Freer, 2010). In this study, participants completed an in-depth survey that required approximately forty minutes to complete. Subsequent to the survey, $16(46 \%)$ of the thirty-five survey respondents attended one of three forty-five minute focus group interviews. These were held once initial coding of survey data had been completed.

The survey instrument combined open and closed questions with ample space for comment. The survey was designed specifically for this study, and it was trialled with a number of students. The survey began with questions about educational and musical background and then asked about existing musician and music teacher identities. After this, respondents considered their future identities. They also thought about their definitions of a music teacher and a musician, and they shared any perceived differences between themselves and their definitions. Next, respondents considered their career goals and aspirations, and they visualised themselves as aspiring teachers. The questions addressed in this paper related to identity and career aspirations. The survey questions are summarised at Appendix A.

A third-party research assistant transcribed the survey data, and the signed consent forms were collected and kept separately. The researchers employed a naturalistic coding process that started with reading the responses without applying codes. Following Glaser and Strauss (1967), this led to a constant comparative analytical scheme that involved unitizing and categorizing the text, which was broken into units of information. These units were subsequently brought together into provisional categories relating to the same content. The 
analysis informed the development of focus group interview questions, including summary points from the survey data for discussion and comments. Whilst these questions were central to the focus group discussion, participants were encouraged to introduce new themes or to expand on issues they felt to be important. To ensure that students felt free to contribute their views without negative consequences, the second author, one of the music lecturers, was not present at the interviews. Interviews were subsequently transcribed by an independent person and then coded in the same way as the survey data to create a combined dataset.

\section{Findings and discussion}

Theme 1: Motivation to become music teachers

Early exposure to teaching. Early exposure to teaching is thought to assist with the development of positive teacher identities among PSMTs for whom teaching has been perceived as a fall-back career (Miller \& Baker, 2007). As described earlier, PSMTs in Singapore are fortunate in this respect as they have multiple opportunities for early exposure.

Within the survey, PSMTs were asked when and why they began to think about becoming a music teacher. The undergraduate students and PGDE secondary track PSMTs identified this as being at 16.9 and 15.4 years respectively. In contrast, on average the PGDE primary track students started to think about teaching as a career when they were 25.3 years old. The number of survey respondents is too small to make any general claims, except that this difference may not be too surprising given that the primary teaching group comprised a number of second-career aspiring teachers. The age differential between programme and cohort may be a point of difference to examine in future studies involving larger student cohorts.

Asked in the written survey what prompted their decisions to become music teachers, six PSMTs referred to their experiences as private instrumental teachers or as untrained relief or contract teachers in schools. One participant expanded on this during a focus group interview:

I actually decided to stay in teaching after one year of contract, so in a sense, I really chose after I had a sense of what teaching in a mainstream school was about. Yeah, so I decided to stay because I felt that I was learning so many new things. (PGS 2)

Internship experiences were also important for scholarship holders in the PGDE cohort:

...I think it offers a lot of perspectives as a teacher because previously you're just being a student, like really passive, but then being a teacher you have to be very active, yeah. Flexible, and a lot of different skills. That's unthinkable! (PGS 6) 
Participants also mentioned other experiences of teaching and working with children. During an interview, one undergraduate student (BA 2) revealed that her parents had made the decision for her to study teaching. Her personal interest was aroused only when she began to teach the violin and was moved by the rewarding experience of seeing students make progress in their learning.

Prior teaching experiences emerged as particularly impactful in relation to PSMTs' sense of professional identity. Two interviewees relayed that they began to see themselves as music teachers during their contract teaching (PGP 2 and 4). One PSMT, barely into his second semester of study at the time of the survey, wrote that on the basis of theory and instrumental teaching with young children, "I would see myself as a music teacher already" (BA1-1). Another student had moved into the BA programme after completing her diploma in music education, which meant she had already completed a ten-week teaching practicum. She told of the development of her teaching persona during the earlier practicum:

So in front of the class sometimes you can be quite sad and stuff, but once you step into a class you have to separate yourself from your feelings. And likewise, when you're very angry in class and you go out, you have to separate yourself from that feeling. So, that persona is something that I found during my 10 weeks of practical. It was a process that really shaped me a lot. (BA 2)

Other career previews The decision to become a teacher can be influenced by multiple career previews. Often, these glimpses come through contact with influential teachers (Brand \& Dolloff, 2002). One interviewee (PGP 2) mentioned teacher influence, but for quite a few other participants, the influence was family members who were teachers. In one case, both parents were teachers and the PSMT recalled "imaginary teaching" as a child (BA 1).

For many PSMTs the decision to become a teacher was not unreserved. In some cases this was expressed in terms of an alternative teaching role once contractual teaching obligations had been met. For example, one PSMT expressed the intention to eventually become an adjunct teacher so as to avoid teacher administrative work (BA 2), and a primary track graduate PSMT indicated a preference to teach in a non-school context because of the perception that formal schooling stifles students' desire to learn. The latter PSMT also voiced concerns about the lack of societal and educational value placed on the arts and the associated risk that music teachers could be poorly understood, undervalued and inadequately supported 
by school leaders. It is possible that these insights explain some of the attrition of music teachers to the private sector.

Love for music and career prospects. PSMTs were asked to indicate the factors that influenced their enrolment into a music education programme. Shown at Figure 1, the most common response was the "desire to be a music teacher". This was followed by the "opportunity to study music", a point also voiced by a number of interview participants. As one interviewee remarked:

I like music, that's why. And second thing is ... I like to teach, yeah. So I mean you combine both, and then it's, it's what I like. (BA 3)

In Singapore, the MOE offers attractive employment packages for teachers and it was not surprising that financial considerations were also important influences in career choice, both because of "stable income" (BA2) and career prospects.

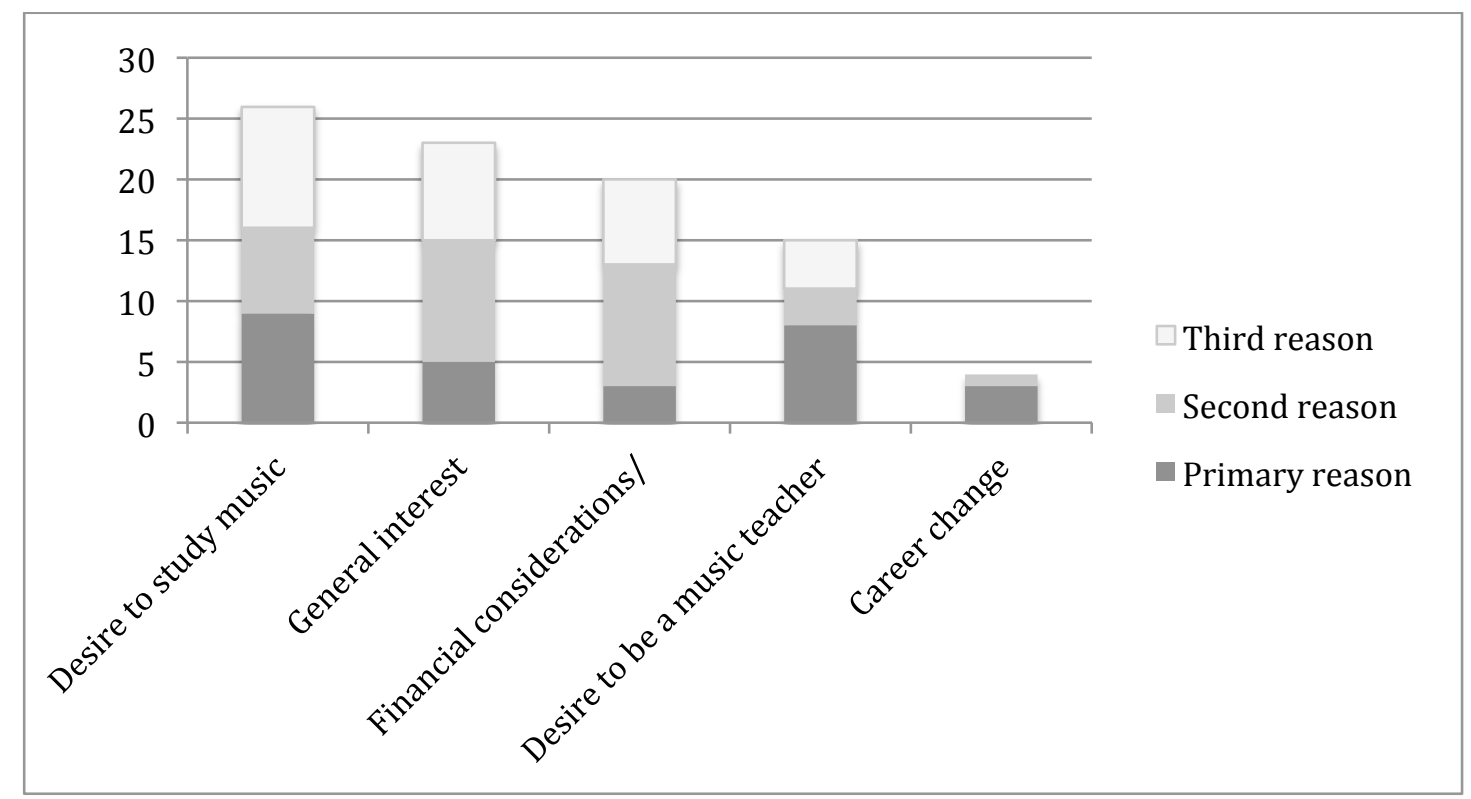

Figure 1: The three most important reasons for choosing to study music education (count)

Theme 2: Identity and self-efficacy as musician and music teacher

Caught between two identities. Ballantyne, Kerchner and Aróstegui (2012, p. 212) note that pre-service teachers self-define as either discipline experts or teachers, based largely on experiences prior to teacher education. Asked how they would define a musician, 29 of the 35 participants referred to roles in performance. Five others used the phrase "music making" and another two wrote of "communicating through music" (Figure 2), suggesting diverse and community oriented views of musicians' work. 


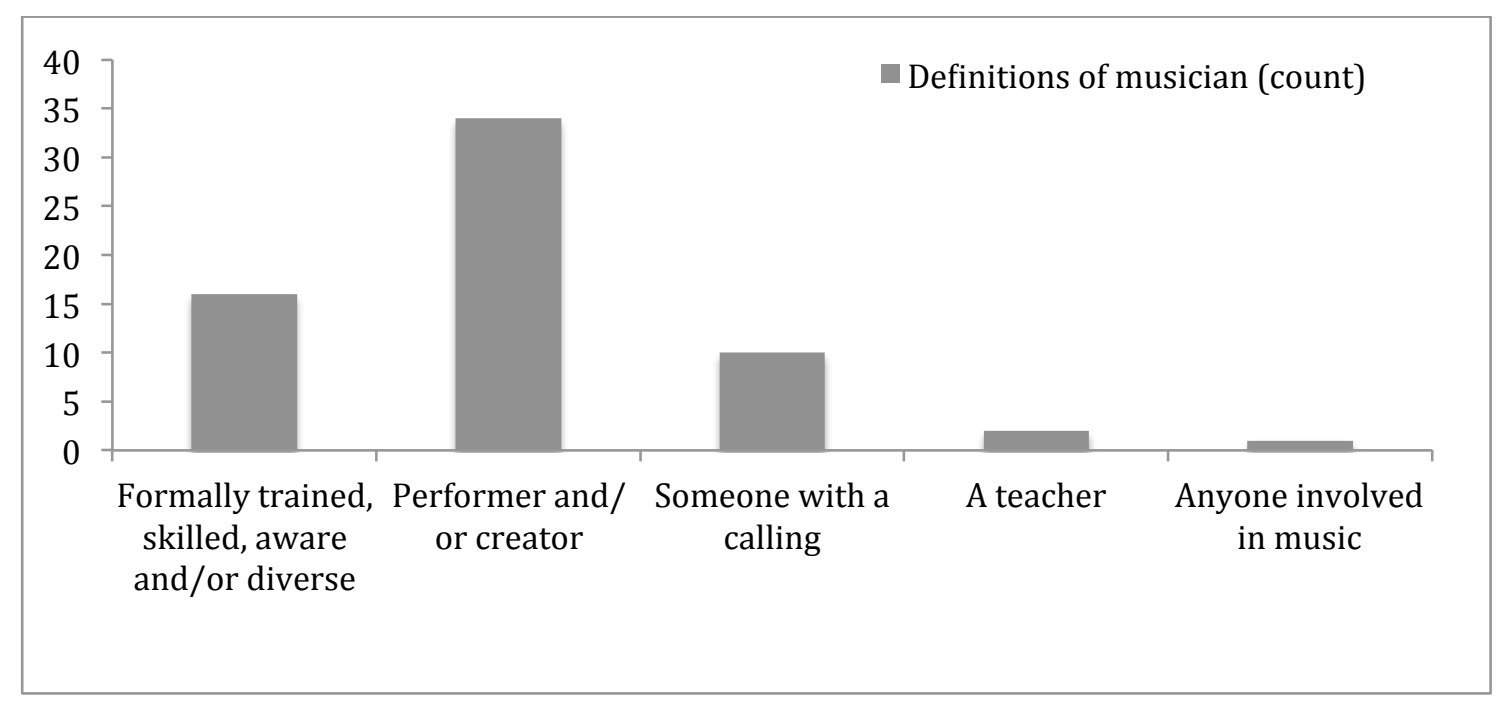

Figure 2: Student definitions of a musician

Given the common tension between musician and music educator roles (Bernard, 2004), we asked participants the extent to which participants saw themselves as musicians and as teachers. Only three undergraduates, all in the first two years of study, were yet to see themselves as musicians. Amongst the PGDE secondary track PSMTs who had completed a music degree, all but one saw themselves as musicians. Participants who had come with degrees other than music also identified themselves as musicians, citing involvement in community music and instrumental teaching experience.

A similar open question inquired about the students' sense of teacher identity. At first glance, the undergraduates were mindful of being in the early stages of teacher training, with only 13 of the 21 students thinking of themselves as teachers completely or to a large extent. However, finer analysis showed that self-identity as a teacher did not depend on seniority in the programme: six of the ten final-year students compared with seven of the eleven earlieryear students expressed strong teacher identity. Within the PGDE secondary cohort, all but two students saw themselves as music teachers. For one PSMT the music teacher identity incorporated all music-related activities.

I see myself as a music teacher when I perform music for others, when I give musical direction in choirs/bands and even through my discussions with friends. By spreading the presence and awareness of music in these out-of-school activities, I do see myself as fulfilling the roles of a music teacher providing music education. (PGS 4)

The survey responses suggest that most students identified themselves as both musicians and teachers regardless of the programme they were enrolled in. Asked how they would reply to the question, "What do you do?", this group expressed their dual musician-teacher identity: a 
"musician who teaches music", "musician and music educator", "school teacher and a professional musician", "I teach and 'I do music"”. A number of respondents emphasised their belief that being a musician is an important aspect of being a music teacher.

A subsequent question pressed PSMTs to rank the two identities, and only two of them thought of their teacher and musician selves as being on equal terms. We suspect that at least some PSMTs were still wrestling with the tensions between being a teacher and a performing musician. Although the participants were studying to become teachers, many of them relayed that "being a musician at heart" is important for a music teacher.

I feel that it is important to remain active as a musician so that you have more opportunities to draw from various experiences and apply that in your teaching, which will help to make your teaching varied and relevant. (PGS4)

From present to future identities. When the future professional identity was brought into the picture, the responses revealed further differences in thinking. For example, all five participants who reported incongruence between their present and desired professional identities saw themselves primarily as music teachers, whereas the participants who identified first as musicians reported no conflict between the two. For a number of students, the musician self was positioned as integral to the practising teacher self, as noted above. The reasons for these differences, and the question of whether such differing professional selfperceptions are an indicator of aspirational frustration merit further research.

Self-efficacy and concerns. Ballantyne (2005) has suggested that teachers' perception of their own musical abilities influences their professional identity - that is, the greater their selfefficacy as a performer, the greater the likelihood of them seeing themselves as a 'musician'. Despite its logic, this was not strongly borne out in the present study. In Singapore, many children take practical music examinations when they learn music privately: for example, the Associated Board of the Royal Schools of Music (ABRSM) graded examinations (see http://au.abrsm.org/en/home), derived from the UK. These exams recognise achievement in music practice, musicianship or theory from beginner (grade 1) to advanced level (grade 8, Diploma, Licentiate and Fellowship levels). Grades 6 and above are recognised for postsecondary study in the UK, and the levels are recognised in many countries as a common benchmark. 
All participants had attained at least the pre-requisite Grade 5 examination pass in instrumental or vocal performance. Six of the fifteen undergraduate participants had attained at least Grade 8; some had also completed a three-year music diploma course. If these formal qualifications can be taken as a proxy indicator of musical performance competency, we note that advanced performance skills may not translate into PSMTs' identity confusion or conflict as music teachers, contrary to findings elsewhere.

Similarly, all eight PGDE participants who held a music degree reported having at least Grade 7 in performance before enrolling into their music degrees. Only two of this cohort indicated that they did not yet see themselves as teachers; the remaining six saw themselves as both musicians and teachers. Similarly, three of the four PGDE primary track PSMTs with at least a Grade 6 in instrumental performance saw themselves as music teachers.

Students were asked to describe their musician self-efficacy in relation to teaching, and again there was no evidence that higher instrumental performance levels align with higher self-efficacy among PSMTs. In fact, some participants with a high performance competency reported feeling inadequate as a musician within a teaching setting. As one PSMT explained:

[I am] adequately enough to be a decent music teacher, but not enough to be an exceptional music teacher. Music teachers require different skills from those required of a musician. (PGS1)

Participants conveyed that an undergraduate performance degree does not equate to welldeveloped musical competence for the purposes of classroom music teaching. Elsewhere in the data, participants had voiced their concern that their practical musical skills and "talent" were insufficient for teaching. As seen below, these comments often related to the need for a working knowledge of multiple instruments and for skills beyond performance.

[My skills are] not adequate. I'm restricted mostly to my instrument of training i.e. piano. I should pick up and learn a variety of instruments to be able to bring different ideas to my lessons. I'm not knowledgeable or exposed enough to music around the world. Still quite restricted to music that I like/prefer (not pop!). (PGP3)

Participants also expressed concerns about their teacher efficacy. Responses were coded according to a-priori codes developed from a related project (see hidden, 2012). These covered technical knowledge and skills, social and professional communication, lateral thinking, organisation, teamwork, personality, intelligence, teaching as high status and teaching as a challenging career. In line with other studies (see Peters, 2012), chief among participants' concerns were inadequate technical knowledge and skills related to teaching 
practice (mentioned by $84 \%$ of participants), including pedagogical knowledge and classroom management. Within the cohort, particular areas of concern included aural skills, improvisation, the need to work in multiple genres, conducting, composition, and general musicianship skills.

Many of the students' concerned are discussed elsewhere and they are not surprising per se. Few students felt prepared to meet the diverse demands placed on beginning teachers, who needed to be "armed with their arsenal of knowledge (performance, theoretical etc.) and cultivation of good music pedagogical skills and music class management" (BA1). The same student didn't expect to graduate with a 'full arsenal' and expected to "increase both musical and pedagogical competency over the next 2 years while I am in training" (BA1).

\section{Theme 3: Career tenure and teacher attrition}

Having noted professional identities, we next examine the length of time participants intended to work as teachers. This was probed from different angles:

- What would you like/expect to be doing three to five years after graduation?

- How do you see your future in terms of your career and/or involvement in music teaching?

- For how long do you intend to work as a music teacher?

- What is your ultimate career goal?

The "three to five years" demarcation was prompted by the fact that many participants held a three- or four-year employment bond to serve after graduation in return for their sponsorship from the MOE. A few PSMTs had longer bond periods (up to seven years) because the ministry had also sponsored their previous higher education studies.

Thirty-four of the 35 participants intended to be teaching five years after graduation; however, only 18 of them intended to remain in teaching beyond that time. Participants with performance levels of Grade 8 and above intended to remain in teaching for fewer years than those at Grades 6 and 7, and the Grade 6 and 7 cohort intended to teach for a shorter period than those at the entry requirement of Grade 5. Due to the small number of participants we do not seek to generalise about any relation between the self-reported strengths of PSMTs' performance skills and the desire to remain in teaching. We do, however, note that PGDE participants with higher performance grades were more likely to have graduated from performance-based undergraduate degree programs in Singapore or from overseas. It is possible, then, that their intentions to pursue performance careers were as yet unmet. This 
raises the question of whether and how practising teachers might be supported and even encouraged to retain a level of performance engagement during their period of service.

The data highlighted a number of factors that may influence PSMTs' desire to remain in music teaching. Since they had yet to embark on their teaching career, it might be premature to speak of praxis shock. However, we note participants' awareness of recognised challenges:

My main concern is not being able to engage or sustain the interest of students (PGS 4)

Music teachers should be spontaneous and enthusiastic about what they're teaching. Be able to connect with students through music learning. However, my personality is quite reserved. (PGP 3)

Whatever their motivations to become music teachers, two of the graduate secondary cohort voiced that they had harboured doubts about their career choice even before starting their teacher training. These participants candidly expressed the tension between music teaching and other music-related career options:

... you're 18, 19 [years old] ... teaching was inspiring when you think about it before, but as I went through university it just felt like my world of a music career opened a bit more. And so, yeah definitely I've thought about other options. And the draw to just remain in teaching in a sense decreased. (Focus group interview)

... in Singapore, music is usually linked to teaching ...I mean the career ... but when we go overseas to study, we start to see that it has a bigger market and different areas and, so there's more options, so that really affects the way we look at our careers and, yeah, gives us more scope. (Focus group interview)

Career uncertainty is understandable, especially when professional identities are still at a nascent stage. However, Hallam (2006) emphasises that under-formed teacher identities can result in attrition from teaching and from pre-service education. A consideration in this study was the commitment made to a bonded period of employment before students embarked on their undergraduate music studies. Such contracts inevitably have an impact on student teachers' career motivation and intentions, particularly if career intentions change.

\section{Closing comments}


This study investigated the career motivations and intentions of pre-service music teachers (PSMTs) in Singapore. In return for study sponsorship, participants were contractually bonded to teach with the MOE for up to seven years post-graduation. A key findings is that students' emerging career intentions had led many of them to plan their exit from teaching once their bond commitment had been met. Participants' career intentions related to their identity: PSMTs who defined themselves first and foremost as music teachers were more likely than their peers to plan teaching careers that extended beyond the period of their bond, whereas those who did not include music teacher in their identities were less likely to plan longer-term teaching careers. This signals the need for early placements to help PSMTs foster a stronger teacher identity. At the same time, perhaps the notion of a portfolio career may be introduced to help them reconcile their dual musician-teacher identities as well as achieve multiple career aspirations.

Some participants aligned their career thinking with their personal and professional development since secondary school, at which point they had already committed to teaching by accepting a scholarship. Here, recruiters may wish to recognise the social construction of identity through negotiation and reconciliation of multiple experiences that have yet to be experienced by potential recruits. A possible solution is to consider alternative pathways and flexible models of employment that allow teaching artists to work on a part-time basis whilst sustaining other music interests.

The second key finding concerns the belief that PSMTs' perceptions of their musical abilities influence their professional identity. In the current study, instrumental performance proficiency did not align with participants' self-identity as teachers. It did, however, align with their intentions to remain in teaching. Many participants expressed reservations about being teachers in the longer term, and some participants were already planning their postteaching careers. Participants with high instrumental performance proficiency appeared no more likely than their peers to define themselves as adequate musicians in relation to teaching.

Given the commonality of plural, ambiguous and sometimes disparate musical identities among student musicians (Draves, 2014; Haston \& Russell, 2012), the findings of this study reinforce the need to help PSMTs bring together their identities into a composite musician self. PSMTs should explore what it is to be a musician and (within this) a music teacher, drawing on multiple stories for inspiration. We accept that in some ways this approach may be out of line with the intention of higher education programmes and recruiters, which in this case was the provider of music teachers for Singaporean schools. Our findings, however, 
suggest that such discussions are crucial when contracts and bonds commit secondary school students to a teaching career path for some years after graduation.

Incompatibility between different identities (such as performer and teacher, for example) can cause dissatisfaction with work and career ([hidden], 2009); in this case, the dissatisfaction was expressed before participants' teaching careers had begun. The identity conflict or tension expressed by many of the participants can be explained by their intense involvement in two or more social worlds that are premised on different identities and which encounter competing role demands. These participants also have to make different, sometimes opposing public representations of each world. As a consequence, people in this situation can feel fragmented (Ibarra, 2003) and can oscillate between 'holding on' to and 'letting go' of established identities (Shepherd, 2003).

PSMTs' career identities shift as they progressively encounter work-related situations and learn more about careers in the field they have chosen (Beijiaard, Meijer, \& Verloop, 2004). The participants in this study expressed concerns about classroom management, possible lack of whole-school support for music education, and meeting the demands of delivering a multicultural or a multi-genre music curriculum. As is the case in other countries, many PSMTs in Singapore are classically trained musicians for whom improvisation is not a familiar musical skill. Improvisation emerged as a commonly anticipated praxis concern because of the recent emphasis on incorporating improvisation in general music teaching. The extent to which these fears are realised in practice warrants further investigation. The study further emphasises the need for discussion about possible future selves and careers in high schools and within higher education. It also strengthens calls for research to determine how commonly held fears (for example, the need to teach across genres) might be addressed within existing programmes.

Implications include the need to support educators as they develop students' broad and inclusive music teacher identities at the earliest stages of teacher training. For bonded PSMTs this includes discussion about the period of their bond and the extent to which developing interests might be accommodated. Understandably, careers in music education can offer a relatively high level of employment security whilst retaining a connection with music and the musician identity (Fouad \& Bynner, 2008). In the case of Singapore, sponsored graduates are not only assured of a teaching position with an attractive employment package, they are obliged to take it. It follows that school music teaching is an attractive choice for secondary students and for graduates interested in a variety of music careers. Future research might investigate how the intended attraction and retention effects of such employment contracts might be better balanced against the attrition concerns that led to this study. 
References (authors' publications removed for review)

Alsagoff, L. (2013). Editorial. Research in Education at the National Institute of Education, Singapore, 9, 2.

Ballantyne, J. (2005). Identities of music teachers: Implications for teacher education. In M. Cooper (Ed.), Teacher education: Local and global. Australian teacher education association conference proceedings, (pp. 39-44). Gold Coast: Australian Teacher Education Association.

Ballantyne, J., Kerchner, J., \& Aróstegui, J. L. (2012). Developing music teacher identities: An international multi-site study. International Journal of Music Education, 30(3), 211-226.

Beijaard, D., Meijer, P., \& Verloop, N. (2004). Reconsidering research on teachers' professional identity. Teaching and Teacher Education, 20(2), 107-128.

Bernard, R. (2004). A dissonant duet: Discussions of music making and music teaching. Music Education Research, 6(3), 281-298.

Bernard, R. (2005). Making music, making selves: A call for reframing music teacher education. Action, Criticism and Theory for Music Education 4(2).

Brand, M., \& Dolloff, L. (2002). Fantasies and other romanticized concepts of music teaching: A cross-cultural study of Chinese and North American music education students' images of music teaching. International Journal of Music Education, 39(1), 17-30.

Cleaver, D., \& Ballantyne, J. (2013). Identities of music teachers: Implications for teacher education. International Journal of Music Education. Published 'online first': DOI: $10.1177 / 0255761413508066$

Dixon, M., \& Liang, R. (2009). Singapore teachers' espoused beliefs (TEB): Links to practice (Final Research Report No. CRP 11/07 MD). Singapore: National Institute of Education.

Dolloff, L. A. (1999). Imagining ourselves as teachers: The development of teacher identity in music teacher education. Music Education Research, 1(2), 191-208.

Draves, T. J. (2014). Under construction: Undergraduates' perceptions of their music teacher roleidentities. Research Studies in Music Education, 36(2), 199-214.

Fouad, N. A., \& Bynner, J. (2008). Work transitions. American Psychologist, 63(4), 241-251.

Freer, P. K. (2010). Two decades of research on possible selves and the 'missing males' problem in choral music. International Journal of Music Education, 28(1), 17-30.

Glaser, B. G., \& Strauss, A. (1967). The discovery of grounded theory: Strategies for qualitative research. Chicago: Aldine-Athestor.

Hamman, D., Gosselin, K., Romano, J., \& Bunuan, R. (2010). Using possible-selves theory to understand the identity development of new teachers. Teaching and Teacher Education, 26(7), 1349-1361. 
Hargreaves, D. J., MacDonald, A. R., \& Miell, D. E. (2002). What are musical identities, and why are they important? In A. R. MacDonald, D. J. Hargreaves \& D. Miell (Eds.), Musical identities (pp. 120). OUP.

Hargreaves, D. J., \& Marshall, N. A. (2003). Developing identities in music education. Music Education Research, 5(3), 263-273.

Hargreaves, D. J., Marshall, N. A., \& North, A. C. (2003). Music education in the twenty-first century: A psychological perspective. British Journal of Music Education, 20(2), 147-163.

Haston, W., \& Russell, J. A. (2012). Turning into Teachers: Influences of Authentic Context Learning Experiences on Occupational Identity Development of Pre-service Music Teachers. Journal of Research in Music Education, 59(4), 369-392.

Hawkey, K. (1996). Image and the pressure to conform in learning to teach. Teaching and Teacher Education, 12(1), 99-108.

Ibarra, H. (2003). Working identity: Unconventional strategies for reinventing your career. Boston: Harvard Business School Press.

Lau, W. H. (1968). Why teach? A study of motives for teaching as a career. Institute of Education, Singapore.

Lim, S. K., Low, E-L., Ch'ng, A., \& Goh, K. C. (2005). Student teachers' reasons for choosing teaching as a career. Paper presented at the Redesigning Pedagogy: Research, Policy, Practice Conference, May.

Low, E.-L., Lim, K. M., Tay, E. G., \& Ng, P. T. (2009). Building an evidence-base for ITE in NIE: A bridging project (Final Research Report No. OER 13_09). Singapore: National Institute of Education.

McCormack, A., \& Thomas, K. (2003). Is survival enough? Induction experiences of beginning teachers within a New South Wales context. Asia-Pacific Journal of Teacher Education, 31(2), $125-138$.

MacDonald, A. R., Hargreaves, D. J., \& Miell, D. (Eds.). (2002). Musical identities. OUP.

MacIntyre, P., Schnare, B., \& Doucette, J. (2012). Possible selves as a source of motivation for musicians. Psychology of Music, 40(1), 94-111.

Marcia, J. (1966). Development and validation of ego-identity status. Journal of Personality and Social Psychology, 3(1), 551-558.

Marcus, H., \& Nurius, P. (1986). Possible selves. American Psychologist, 41(9), 954-969.

Mark, D. (1998). The music teacher's dilemma - musician or teacher? International Journal of Music Education, 32, 3-23.

Miller, J., \& Baker, D. (2007). Career orientation and pedagogical training: Conservatoire undergraduates' insights. British Journal of Music Education, 24(1), 5-19.

Ministry of Education. (2006). Parliamentary replies, 3 April. http://www.moe.gov.sg/media/parliamentary-replies/2006/pq20060403.htm. 
Ministry of Education. (2009). Report of the primary education review and implementation committee. Ministry of Education: Singapore. http://www.moe.gov.sg/media/press/files/2009/04/perireport.pdf

Ministry of Education. (2012). Parliamentary replies, 13 August. http://www.moe.gov.sg/media/parliamentary-replies/2012/08/teachers-trained-in-visual-art.php

Ministry of Education. (2013). Parliamentary replies, 21 October. www.moe.gov.sg/media/parliamentary-replies/2013/10/class-size-student-outcomes-and-teacherworkload.php

Oyserman, D., \& James, L. (2011). Possible identities. In S. J. Schwartz, K. Luyckx \& V. L. Vignoles (Eds.), Handbook of identity theory and research (pp. 117-145). Rotterdam, The Netherlands: Springer.

Packard, B. W-L., \& Conway, P. (2006). Methodological choice and its consequences for possible selves research. Identity: An International Journal of Theory and Research, 6(3), 251-71.

Roberts, B. A. (1993). I, musician: Towards a model of identity construction and maintenance by music education students as musicians. St. John's, NL: Memorial University of Newfoundland.

Peters, J. H., (2012). Are they ready? Final year pre-service teachers' learning about managing student behavior. Australian Journal of Teacher Education, 37(9), 17-42.

Shepherd, D. A. (2003), Learning from business failure: Propositions of grief recovery for the selfemployed. Academy of Management Review, 28(2), 318-328.

Smilde, R. (2009). Musicians as lifelong learners: Discography through biography. Delft: Eburon Academic Publishers.

Soh, K. C. (1981). Student profiles and motives for teaching of full-time students in the Institute of Education (preliminary report) (Occasional paper no. 7). Singapore: Institute of Education.

Soh, K. C. (1989). Motives for teaching of female Certificate in Education students (Research paper ERU /9/89). Singapore: Institute of Education.

Soh, K. C. (1998). Who has come to teach and why? A cross sectional comparison of four 'generations' of teaching in Singapore. Journal of Applied Research in Education, 2(1), 19-34.

The Straits Times. (1996, 21 March). Teaching service gets $\$ 420$ million a year boost. Straits Times. http://eresources.nlb.gov.sg/newspapers/Digitised/Issue/straitstimes19960321-1.aspx

Triantafyllaki, A. (2010). Performance teachers' identity and professional knowledge in advanced music teaching. Music Education Research, 12(1), 71-87.

Zhou, M., Chye, S., Koh, C., \& Liu, W. C. (2013). Understanding teacher identity through the use of ePortfolios with pre-service teachers. Paper presented at the Second International Conference on eTechnologies and Networks for Development (ICeND 2013), 4-6 March. 


\section{Appendix A: Summary of survey questions}

\section{Section 1: About you: your educational background}

1. Degree program and major; year of study; teaching subjects

2. Formal qualifications and the years of study

3. Other music qualifications, such as performance grade examinations

4. Non-formal musical learning

5. Musical activities prior to attending NIE

\section{Section 2: You as a musician}

6. What in your view is a musician?

7. Based on this definition, in what sense and to what extent do you see yourself as a musician?

8. Do you see any differences between your view of a musician and you as an individual? $\mathrm{Y} / \mathrm{N}$

a. If yes, what are the differences and how do you feel about them?

b. How do you plan to overcome the differences, and what is the timeframe?

\section{Section 3: Becoming a music teacher}

9. How do you answer if someone asks 'What do you do?'

10. In what sense and to what extent do you see yourself as a music teacher?

11. Do you see differences between your view of a music teacher and you as an individual? $\mathrm{Y} / \mathrm{N}$

a. If yes, what are the differences and how do you feel about them?

b. How do you plan to overcome the differences, and what is the timeframe?

12. Do you see yourself as adequate as a musician in a music teacher setting at this point in time? In what way/s?

13. On the continuum below, please place a cross to mark the point at which you began to think about becoming a teacher (years)

a. What prompted this decision?

14. Why did you choose to take up your present course at NIE, which prepares you to teach music in schools?

a. The 3 most / least important factors?

15. How strong is your desire to be a music teacher? (Likert: not at all, neutral, very strong)

16. What are your aspirations as a music teacher?

17. What would you like / expect to be doing three to five years after graduation?

18. How do you see your future in terms of your career and/or involvement in music teaching?

19. For how long do you intend to work as a music teacher?

20 . What is your ultimate career goal?

21. How close are you to achieving this goal?

22. What are your concerns or fears as an aspiring music teacher?

23. Do you see yourself as a musician first then a music teacher or vice versa?

a. Is this congruent with what you would like?

24. To help us understand your idea of yourself as an aspiring teacher, please draw yourself as a music teacher and describe what you have drawn.

25. Demographic information including work history, age and gender. 